\title{
Sistem Pelayanan Posyandu Berbasis Web Sebagai Sarana dalam Meningkatkan Kesehatan Ibu dan Anak Di Posyandu Sartika Cikondang
}

\author{
Sri Widaningsih ${ }^{1}$,Fitri Kurnia Efendi ${ }^{2}$ \\ Program Studi Teknik Informatika \\ Fakultas Teknik Universitas Suryakancana Cianjur \\ widaningsihsri@gmail.com ${ }^{1}$,kurniafitri05@gmail.com ${ }^{2}$
}

\begin{abstract}
Abstrak
Dalam setiap organisasi saat ini tentunya dibutuhkan sebuah aplikasi sebagai sarana penunjang dalam suatu kegiatan. Salah satunya dibutukan oleh Posyandu Sartika yang berada di lingkungan kerja Puskesmas Cikondang Kecamatan Bojongpicung Kabupaten Cianjur.

Posyandu merupakan salah satu bentuk upaya kesehatan bersumberdaya masyarakat yang dilaksanakan oleh kader posyandu dan didampingi bidan desa. Sasaran utama posyandu adalah bayi, ibu hamil, serta PUS. Dalam pelaksaan posyandu yang pertama dilakukan adalah pendaftaran, kemudian pelayanan KIA meliputi penimbangan, pemeriksaan kesehatan, imunisasi, PMT, penangulangan penderita diare, dan pelayanan PUS KB.

Penelitian ini bertujuan membuat sebuah aplikasi web untuk mempercepat petugas posyandu dalam mengelola serta menerima dan memberikan informasi secara cepat dan terarah antara petugas posyandu, bidan dan masyarakat. Dengan membuat aplikasi pendaftaran, grafik perkembangan berat badan bayi, informasi jadwal posyandu, imunisasi dan vitamin A, penerimaan informasi yang akan melakukan KB, pengelolaan SIP, mebuat format pengisian BB/TB. Pembuatan sistem informasi ini menggunakan bahasa pemrograman PHP dan famework codeigniter dengan database management system MYSQL.
\end{abstract}

Kata kunci: sistem, PUS, SIP, BB/TB, KIA

\section{Pendahuluan}

\subsection{Latar Belakang Masalah}

Perkembangan Teknologi yang begitu pesat berpengaruh terhadap aktivitas manusia, dimana pada saat ini masyarakat dan organisasi sangat membutuhkannya. Teknologi informasi adalah istilah umum untuk teknologi apa pun yang membantu manusia dalam membuat, mengubah, menyimpan, mengomunikasikan dan/atau menyebarkan informasi (Sawyer, 2007). Salah satunya teknologi dari suatu sistem informasi. Kombinasi dari teknologi informasi dan aktivitas manusia menghasilkan sebuah produk yang disebut sistem informasi. Sistem informasi adalah gabungan yang terorganisasi dari manusia, perangkat lunak, perangkat keras, jaringan komunikasi dan sumber data dalam mengumpulkan, mengubah, dan menyebarkan informasi dalam organisasi Dalam setiap organisasi saat ini tentunya dibutuhkan sebuah sistem sebagai sarana penunjang dalam suatu kegiatan. Salah satunya dibutukan oleh organisasi Pos Pelayanan Terpadu (POSYANDU) Sartika yang berada di lingkungan kerja Puskesmas Cikondang Kecamatan Bojongpicung Kabupaten Cianjur. Posyandu merupakan salah satu bentuk upaya kesehatan bersumberdaya masyarakat yang dilaksanakan oleh kader posyandu dan didampingi tenaga kesehatan puskesmas atau bidan desa, dengan pelaksanaan satu bulan sekali dalam waktu satu tahun. Sasaran utama posyandu adalah bayi, balita, ibu hamil, serta PUS (Pasangan Usia Subur).

Dalam pelaksaan posyandu yang pertama dilakukan adalah pendaftaran, Petugas mencatat setiap pendaftaran untuk ibu hamil dan bayi pada secarik kertas, Saat ini pelayanan pendaftaran dirasa kurang optimal karena hanya menggunakan secarik kertas yang menyebakan penumpukan kertas di posyandu sehingga mudah hilang dan sobek. Pelayanan yang diberikan meliputi penimbangan, Ibu dan anak dibawa ketempat penimbangan, selanjutnya petugas mencatat hasil penimbangan pada secarik kertas pendaftaran kemudian petugas mencatat kembali hasil penimbangan ke dalam buku KIA yang dimiliki anggota posyandu, kemudian petugas mencatat kembali hasil penimbangan dalam buku register bayi balita, dan ibu hamil, hal ini dirasa kurang efektif karena harus berkali kali mencatat hasil penimbangan dalam beberapa data. Selain itu meskipun sudah ada data perkembangan berat badan bayi dalam bentuk grafik namun selisih angka atau presentasi antara data bulan satu dengan bulan lainnya belum jelas.

Selanjutnya dilakukan pemeriksaan kesehatan dan pemberian imunisasi bagi ibu hamil dan bayi. Pemberian imunisasi dan vitamin A untuk anak tidak dilakukan rutin setiap bulannya oleh karena itu anggota posyandu terkadang lupa bahkan tidak mengetahui jadwal imuniasai dan pemberian vitamin $\mathrm{A}$, terutama bagi anggota posyandu yang sedang berada di luar wilayah posyandu yang menyebabkan pemberian imunisasi tidak diikuti, sehingga petugas harus mendatangi setiap rumah untuk memberikan vitamin A.

Untuk pelayanan PUS KB, kendala yang dihadapi adalah ketika terdapat PUS yang akan melakukan KB tetapi bidan tidak membawa peralatan KB, karena tidak setiap saat bidan membawa perlengkapan KB sehingga pelaksanaan $\mathrm{KB}$ terkadang diundur atau bidan harus kembali untuk membawa peralatan KB. 
Saat ini seluruh kegiatan posyandu sartika ditulis dalam beberapa buku register yang disebut buku Sistem Informasi Posyandu (SIP), sehingga pencatatan membutuhkan waktu yang lama, yang menyebabkan keterlambatan dalam pembuatan dan pengiriman laporan kegiatan posyandu. Selain itu dari format data SIP bayi belum adanya format pengisian berat badan menurut tinggi badan (BB/TB),

Dengan adanya permasalahan tersebut, maka diperlukan sebuah sistem untuk mempercepat petugas posyandu dalam mengelola serta menerima dan memberikan informasi secara cepat dan terarah antara petugas posyandu, bidan dan masyarakat. Dengan membuat sistem pendaftaran, grafik perkembangan berat badan bayi dan balita, informasi pemberian imunisasi dan vitamin A, penerimaan informasi yang akan melakukan $\mathrm{KB}$, pengelolaan SIP, mebuat format pengisian indikator berat badan bayi terhadap tinggi badan. Pembuatan sistem informasi ini menggunakan bahasa pemrograman PHP atau Codeigniter dengan database management system MYSQL.

Penelitian ini berjudul Sistem Pelayanan Posyandu Berbasis Web Sebagai Sarana Dalam Meningkatkan Kesehatan Ibu dan Anak di Posyandu Sartika. Aplikasi ini diharapkan mampu membantu petugas posyandu dan masyarakat dalam mengelola, menerima dan memberi informasi pelayanan kesehatan bagi ibu dan anak di posyandu kartini sehingga lebih cepat, dan terarah.

\subsection{Identifikasi Masalah}

Berdasarkan latar belakang tersebut maka dapat diidentifikasi beberapa masalah yaitu :

a. Tidak adanya sistem untuk mengelola kegiatan posyandu termasuk pengelolaan buku SIP sehingga pelaporan menjadi lambat;

b. Kurang optimalnya grafik hasil penimbangan bayi dan balita karena masih dibuat secara konvensional;

c. Tidak adanya informasi jadwal posyandu, imunisasi dan vitamin A bagi anak dan ibu hamil sehingga terkadang anggota posyandu lupa bahkan tidak mengetahuinya;

d. Tidak setiap saat bidan membawa peralatan KB, sehingga tidak jarang ibu atau PUS (pasangan usia subur) KB mengundurkan waktu;

e. Dari format data SIP bayi balita, belum adanya format berat badan terhadap tinggi badan (BB/TB);

\subsection{Maksud dan Tujuan}

Maksud dari penelitian ini adalah untuk membuat sistem pelayanan posyandu berbasis web sebagai sarana dalam meningkatkan kesehatan Ibu dan Anak di Posyandu Sartika, sehingga petugas posyandu diharapkan mampu melakukan proses pelayanan, pengelolaan, pemberian informasi dan penerimaan informasi posyandu secara cepat dan terarah. Adapun tujuan yang didapat dari penelitian ini, yaitu:

a. Mempercepat dalam pengelolaan kegiatan termasuk pengeloaan buku SIP

b. Mengoptimalkan pelayanan pendaftaran

c. Mempercepat dalam mencatat hasil penimbangan

d. Mengetahui dengan jelas perkembangan berat badan bayi dan balita dengan membuat grafik. e. Memberikan pelayanan informasi yang terarah mengenai jadwal posyandu, imunisasi, dan jadwal pemberian vitamin A melalui sistem

f. Menerima informasi dari ibu atau PUS yang akan melakukan KB melalui sistem sehingga bidan membawa peralatan $\mathrm{KB}$ dengan lengkap

g. Membuat format pengisian berat badan bayi terhadap tinggi badan $(\mathrm{BB} / \mathrm{TB})$

\subsection{Batasan Masalah}

Agar pembahasan terarah dan permasalahan yang dihadapi dapat diselesaikan dengan tepat, maka batasan masalah penelitian ini adalah:

- Membahas Pengelolaan SIP

- Membahas Pengelolaan Pendaftaran

- Membahas Pembuatan grafik perkembangan berat badan bayi

- Membahas Pemberian informasi jadwal posyandu, imunisasi dan pemberian vitamin A

- Membahas penerimaan informasi dari PUS yang akan melakukan KB

- Membuat format pengisian berat badan terhadap tinggi badan (BB/TT) untuk bayi

- Tidak Membahas mengenai Posyandu lansia

\section{Tinjauan Pustaka}

\subsection{Kader Posyandu}

Kader Posyandu yang selanjutnya disebut kader adalah anggota masyarakat yang bersedia, mampu dan memiliki waktu untuk menyelenggarakan kegiatan posyandu secara sukarela (Permen Dalam Negeri no. 19 tahun 2011).

Kader Posyandu adalah anggota masyarakat yang dipilih, bersedia, mampu, dan memiliki waktu untuk mengelola kegiatan posyandu (Pergub no. 53 tahun 21015).

\subsection{Pelayaan}

Pelayanan adalah proses pemenuhan kebutuhan melalui aktivitas orang lain secara langsung (Moenir, 199 : 16). Menurut Groonros (19990:27) dalam Ratminto dan Atik (200:2) pelayanan adalah suatu aktivitas atau serangkaian aktivitas yang bersifat tidak kasat mata (tidak dapat diraba) yang terjadi sebagai akibat adanya interaksi antara konsumen dengan karyawan atau hal-hal lain yang di sediakan oleh perusahaan pemberi pelayanan yang dimaksudkan untuk memecahkan permasalahan konsumen atau pelanggan.

\subsection{Sistem}

Menurut Jogianto (2005 : 2) mengemukakan bahwa sistem adalah kumpulan dari elemen-elemen yang berinteraksi untuk mencapai suatu tujuan tertentu.

Sistem secara fisik adalah kumpulan dari elementelemnt yang beroprasi bersama-sama untuk melakukan suatu kegiatan untuk menyelesaikan suatu sasaran Davis, G.B, (1991 : 45).

\subsection{SIP (Sistem Informasi Posyandu)}

Menurut Kementrian Kesehatan Republik Indonesia (2011 : 3) SIP adalah tatanan dari berbagai komponen kegiatan posyandu yang menghasilkan data dan 
Sri Widaningsih ${ }^{1}$,Fitri Kurnia Efendi ${ }^{2}$, Sistem Pelayanan Posyandu Berbasis Web Sebagai Sarana dalam Meningkatkan Kesehatan Ibu dan Anak Di Posyandu Sartika Cikondang

informasi tentang pelayanan terhadap proses tumbuh kembang anak dan pelayanan kesehatan dasar ibu dan anak yang meliputi cakupan program, pencapaian program, kontinuitas penimbangan, hasil penimbangan dan partisi masyarakat.

Manfaat SIP adalah sebagai bahan acuan bagi kader posyandu untuk memahami permasalahan sehingga dapat mengembangkan kegiatan yang tepat dan disesuaikan dengan kebutuhan sasaran. Dan sebagai informasi yang tepat guna mengenai pengelolaan posyandu, agar berbagai pihak yang berperan dalam pengeolaan posyandu dapat menggunakannya untuk membina posyandu demi kepentingan masyarakat.

\subsection{Unified Modelling Language (UML)}

Unified Modelling Language (UML) adalah keluarga notasi grafis yang didukung oleh meta-model tunggal, yang membantu pendeskripsian dan desain sistem perangkat lunak, khususnya sistem yang dibangun menggunakan pemrograman berorientasi objek (Fowler, 2005).

\section{Analisis Sistem}

\subsection{Analisis Masalah}

Posyandu Sartika adalah salah bentuk upaya kesehatan berbasis masyarakat (UKBM) yang dikelola dan diselenggarakan dari, oleh, untuk dan bersama masyarakat dalam penyelenggaraan pembangunan kesehatan guna memberdayakan masyarakat dan memberikan kemudahan kepada masyarakat dalam memperoleh pelayanan kesehatan dasar/sosial dasar untuk mempercepat penurunan Angka Kematian Ibu dan Angka Kematian Bayi. Pelayanan yang diberikan di posyandu meliputi Kesehatan Ibu dan Anak (KIA), imunisasi, penangggulangan penderita diare, palayanan gizi dan Keluarga Berencana (KB).

Beberapa persoalan yang terjadi di Posyandu Sartikayang terkait dengan pengelolaan Posyandu sebagai berikut :

a. Tidak adanya sistem untuk mengelola kegiatan posyandu termasuk pengelolaan buku SIP sehingga pelaporan menjadi lambat

b. Pelayanan pendaftaran hanya ditulis pada secarik kertas yang menyebakan penumpukan kertas di posyandu sehingga mudah hilang dan sobek.

c. Kurang optimalnya grafik hasil penimbangan bayi karena masih dibuat secara konvensional

d. Tidak adanya informasi jadwal posyandu, imunisasi, dan jadwal pemberian vitamin A sehingga terkadang anggota posyandu lupa bahkan tidak mengetahuinya

e. Tidak setiap saat bidan membawa peralatan $\mathrm{KB}$ sehingga tidak jarang yang akan melakukan KB dilakukan dilain waktu.

\subsection{Analisis Kebutuhan Sistem}

\subsubsection{Kebutuhan Nonfungsional}

Berikut ini adalah analisis kebutuhan nonfungsional dari aplikasi pelayanan posyandu berbasis web sebagai sarana dalam meningkatkan kesehatan ibu dan anak di posyandu sartika.

\subsubsection{Analisa Perangkat Keras}

Spesifikasi minimum perangkat keras yang digunakan untuk menjalankan sistem tersebut diantaranya adalah sebagai berikut :

a) Processor intel

b) RAM 2GB

c) Monitor, Resolusi 1024 x 768 pixel

d) Hardisk

e) Memori

f) Mouse

g) Keyboard

\subsubsection{Analisa Perangkat Lunak}

Perangkat lunak yang digunakan untuk membangun aplikasi pelayanan posyandu berbasis web ini terdiri dari

a) Sistem Operasi Windows

b) Xampp

c) Browser

d) CodeIgniter

e) PHP

f) Balsmiq Mockup

g) Sublime

\subsection{Kebutuhan Fungsional}

\section{Usecase Diagram}

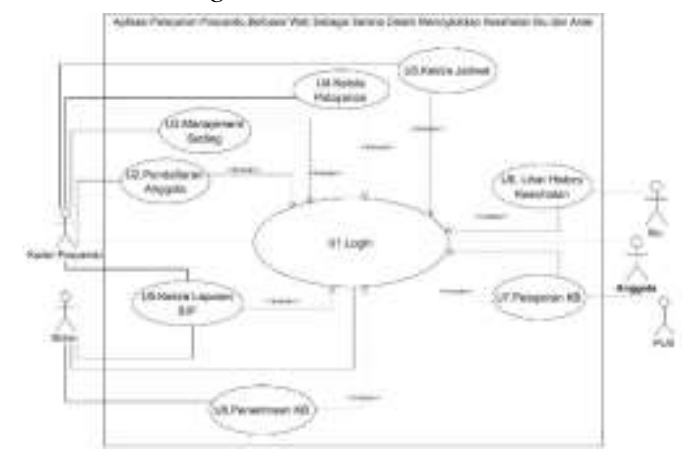

Gambar 1 Use case Diagram

Keterangan : Dari gambar use case diagram Aplikasi Pelayanan Posyandu Berbasis Web Sebagai Sarana Dalam Meningkatkan Kesehatan Ibu dan Anak di Posyandu Sartika terdapat 4 aktor yang dapat masuk ke dalam sistem, terdiri dari kader posyandu, bidan, ibu hamil, serta PUS. Dan terdapat 9 usecase meliputi login, kelola pendaftaran anggota, management setting, kelola jadwal, lihat history kesehatan, pelaporan KB, penerimaan $\mathrm{KB}$, dan kelola laporan SIP.

. 2. Class Diagram

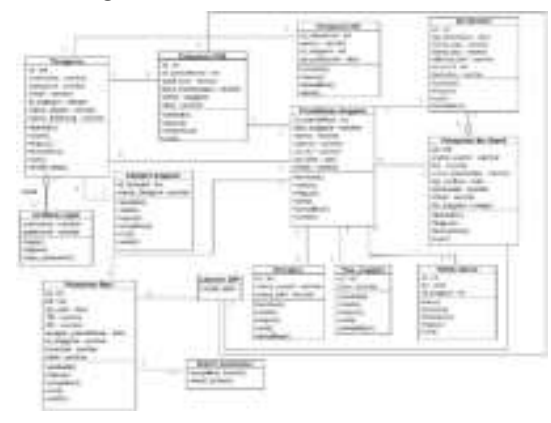

Gambar 1 Class Diagram 
Dalam class diagram diatas terdapat 15 class diagram yang terdiri dari class verifikasi login, class pengguna, class kategori pengguna, class tipe anggota, class orangtua, class pendaftaran anggota, class pelaporan $\mathrm{KB}$, class obat, class imunisasi, class bayi, class ibu hamil, class ibu bersalin, class PUS, class kelola jadwal, class history kesehatan, class SIP,

4. Deployment Diagram

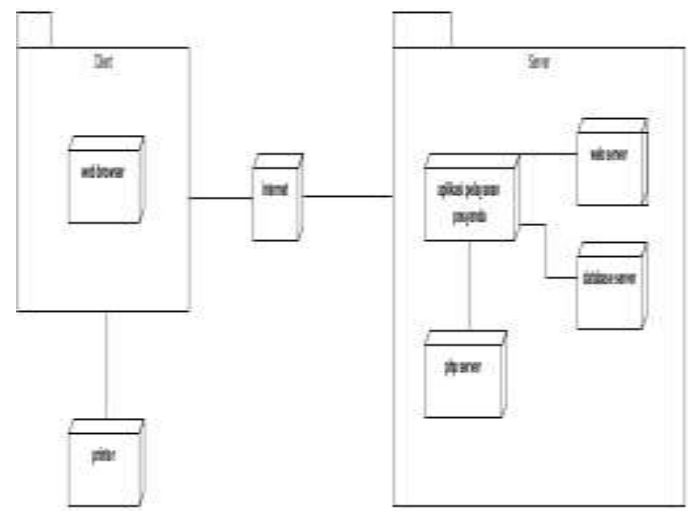

Gambar 3 Deployment Diagram

Diagram tersebut menjelaskan perancangan implementasi pada sebuah aplikasi posyandu yang akan dibuat. Didalam gambar tersebut terdapat dua buah simbol package yang menggambarkan sebuah komputer client dan server. Dengan nama server iix72.rumahweb.com. Pada gambar tersebut terdapat node yang telah diberi nama sebagai penggambaran sebuah perangkat keras dan perangkat lunak yang ada dilingkungan aplikasi pelayanan posyandu.

\section{Perancangan Sistem}

1. Entity Relationship Diagram (ERD)

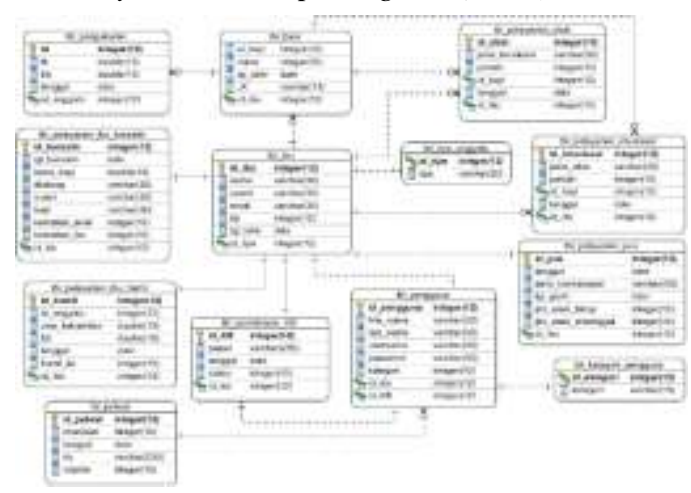

Gambar 4 Perancangan Hardware

Pada Entity Relationship Diagram terdapat 13 ERD sebagai berikut :

a. Relasi tabel ibu dengan tabel pengguna relasinya one to one

b. Relasi tabel ibu dengan tipe anggota relasinya one to one

c. Relasi tabel ibu dengan tabel bayi relasinya one to many

d. Relasi tabel pelayanan imunisasi dengan tabel ibu relasinya many to one

e. Relasi tabel pelayanan obat dengan ibu relasinya many to one f. Relasi tabel pengukuran dengan tabel bayi relasinya many to one

g. Relasi tabel pelayanan imunisasi dengan tabel bayi relasinya many to one

h. Relasi tabel pelayanan obat dengan bayi relasinya many to one

i. Relasi tabel pelayanan bulin dengan ibu relasinya one to one

j. Relasi tabel pelayanan bumil dengan tabel ibu relasinya adalah one to one

k. Relasi tabel pelayanan pus dengan tabel ibu relasinya adalah one to one

1. Relasi tabel pengguna dengan tabel kategori pengguna relasinya adalah one to one

$\mathrm{m}$. Relasi tabel pengguna dengan tabel permintaan $\mathrm{KB}$ relasinya adalah one to one

n. Relasi tabel permintaan $\mathrm{KB}$ dengan tabel tabel ibu relasinya one to one

o. Relasi tabel jadwal dengan tabel pengguna relasinya adalah one to many

2. Perancagan Antarmuka
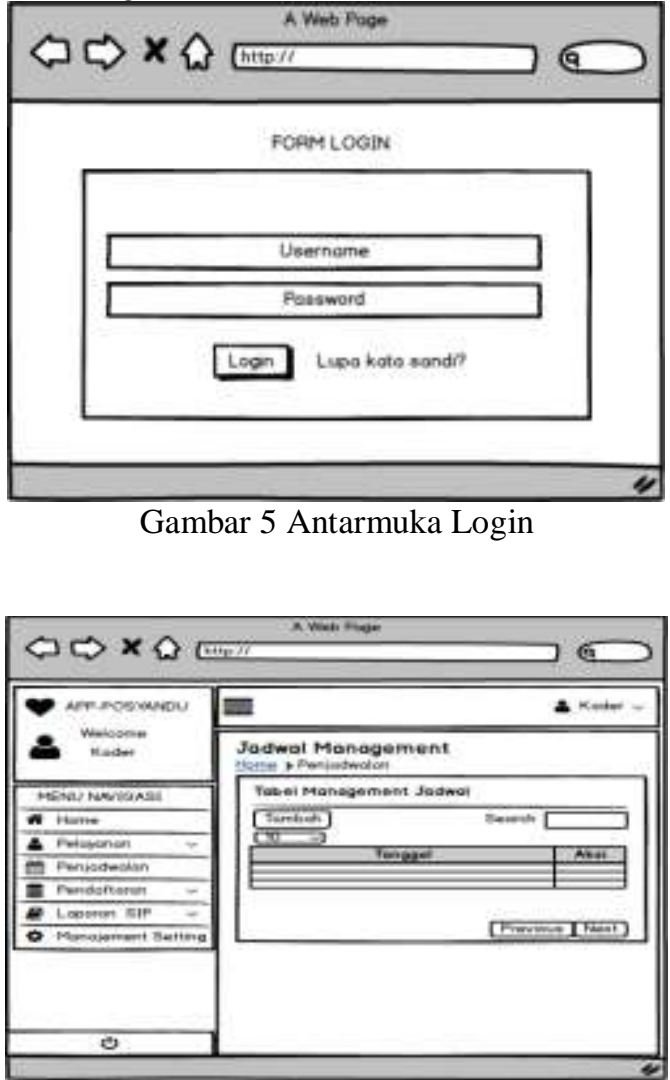

Gambar 6 Antarmuka Penjadwalan 
Sri Widaningsih ${ }^{1}$,Fitri Kurnia Efendi ${ }^{2}$, Sistem Pelayanan Posyandu Berbasis Web Sebagai Sarana dalam Meningkatkan Kesehatan Ibu dan Anak Di Posyandu Sartika Cikondang

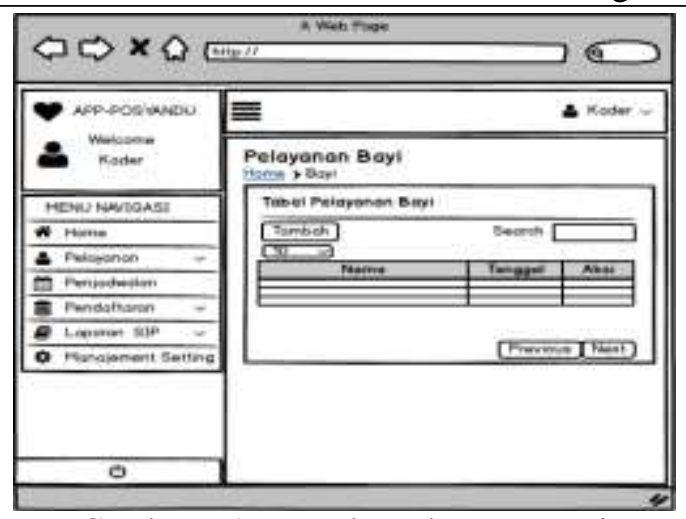

Gambar 7 Antarmuka Pelayanan Bayi

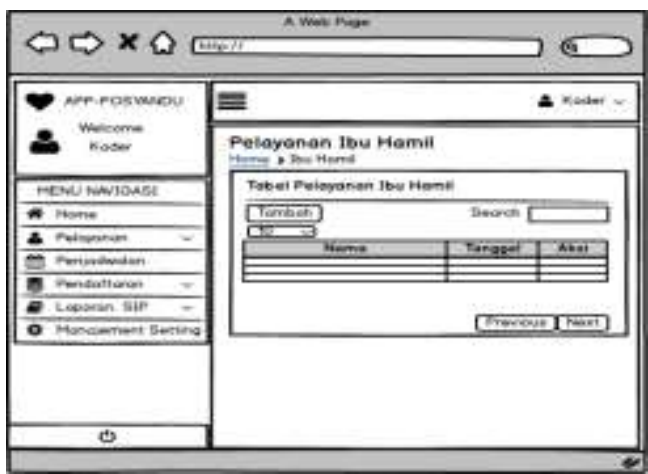

Gambar 8 Antarmuka Pealyanan Bumil

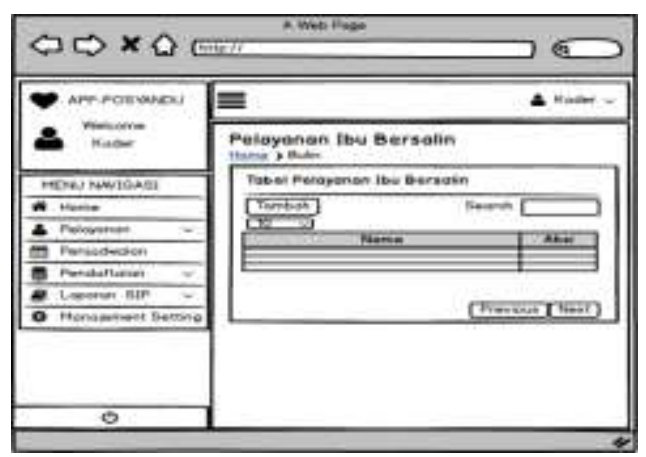

Gambar 9 Antarmuka Pelayanan Bulin

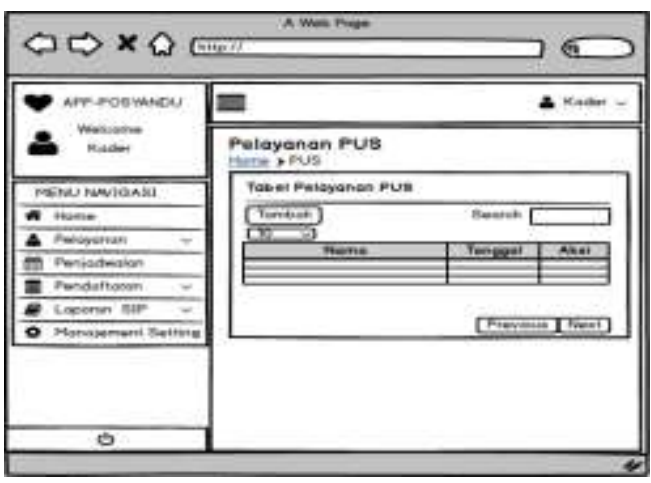

Gambar 10 Antarmuka Pelayanan PUS

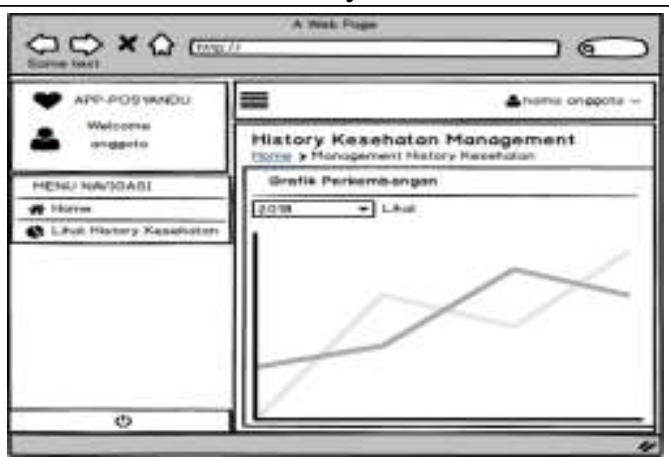

Gambar 11 Antarmuka Grafik BB/TB

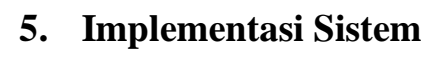

5.1 Implementasi Antarmuka

\section{Login Form}

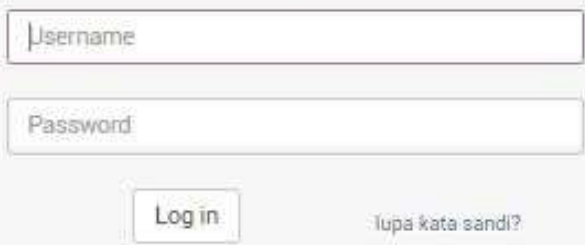

Gambar 12 Login

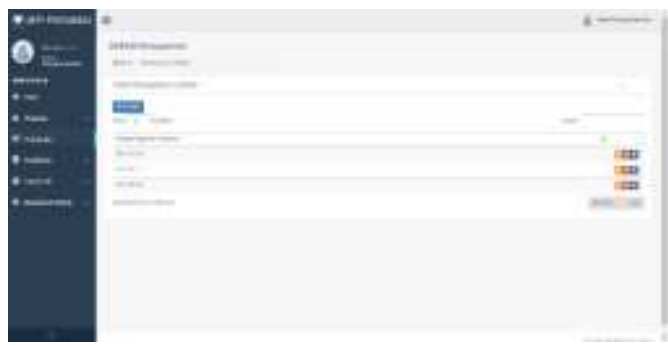

Gambar 13 Penjadwalan

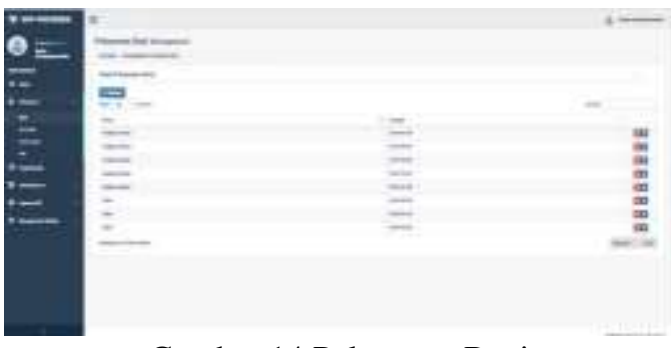

Gambar 14 Pelayanan Bayi

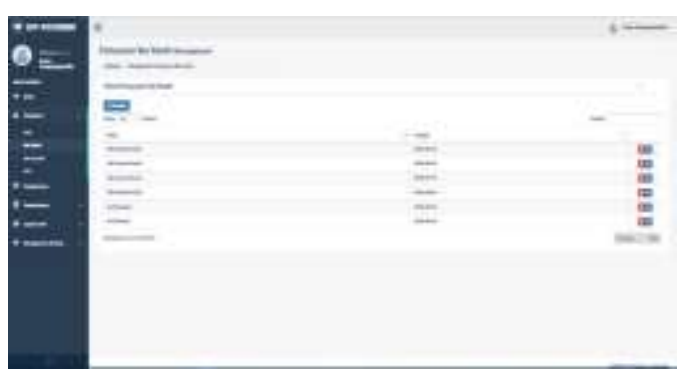

Gambar 15 Pelayanan Ibu hamil 

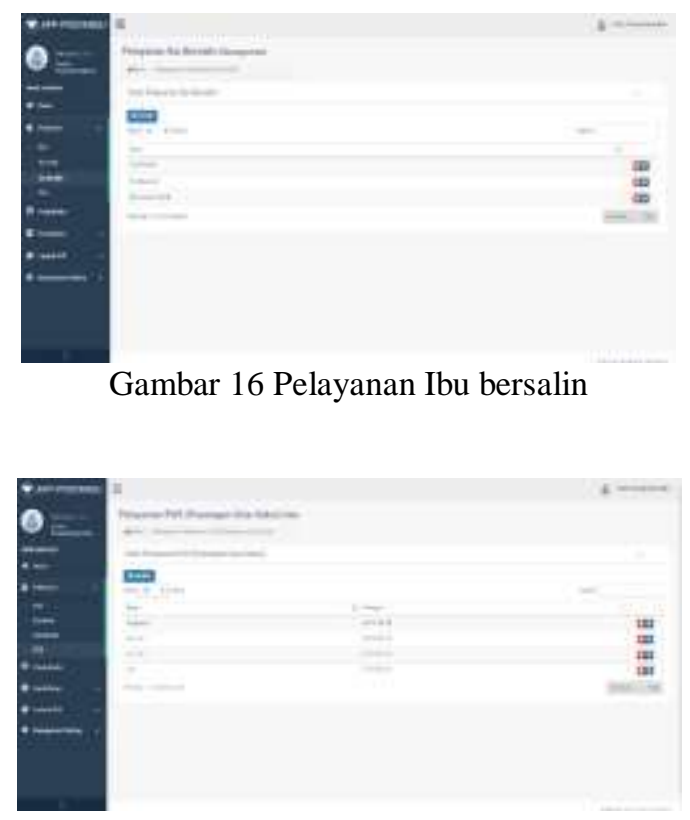

Gambar 17 Pelayanan PUS

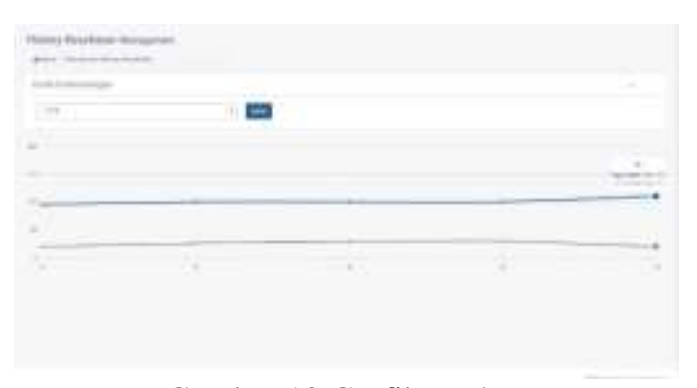

Gambar 18 Grafik BB/TB

\section{Kesimpulan}

Berdasarkan hasil analisis selama melaksanakan penelitian di Posyandu Sartika yang berjudul Aplikasi Pelayanan Posyandu Sebagai Sarana Dalam Meningkatkan Kesehatan Ibu dan Anak di Posyandu Sartika Cikondang, dapat disimpulkan bahwa :

a. Sistem pelayanan posyandu merupakan sebuah sistem berbasis web yang digunakan untuk mengelola, memberikan dan menerima informasi pelayanan posyandu Sartika

b. Sistem pelayanan posyandu dapat membantu kader dan bidan dalam melakukan pengelolaan data posyandu, serta memudahkan anggota dalam menerima informasi jadwal posyandu, jadwal pemberian imunisasi, dan pemberian vitamina secara online, serta menerima informasi yang akan mengikuti $\mathrm{KB}$.

c. Dengan adanya sistem pelayanan posyandu dapat memudahkan petugas posyandu pada saat mencari data yang dibutuhkan karena data sudah tersimpan dalam database, sehingga penyimpanan datapun menjadi lebih aman.

d. Sistem pelayanan posyandu dapat dikembangkan untuk menunjang kinerja ke arah yang lebih luas jangkauannya.

e. Dengan adanya sistem pelayanan posyandu berbasis web di Posyandu Sartika dapat mempermudah
Posyandu dalam pembuatan laporan sehingga pembuatan laporan menjadi efektif dan efisien.

\section{Saran}

Tentunya dalam pembuatan sebuah sistem tidaklah ada yang sempurna. Penulis mengajukan beberapa hal untuk dilakukan pengembangan :

a. Database management seperti relasi antar tabel dan penggunaan field-field pada setiap tabel.

b. Alur logik sistem

c. User interface lebih ditingkatkan

\section{Daftar Pustaka}

[1] Anhar. (2010). Panduan Menguasai PHP \& MySQL Secara Otodidak. Jakarta : Mediakita.

[2] Fauzi, Gunawan. (2011). Peraturan Mentri Dalam Negeri Nomor 19 Tahun 2011 Tentang Pedoman Pengintegrasian Layanan Sosial Dasar dI Pos Pelayanan Terpadu. Jakarta: Kepala Biro Hukum

[3] Fowler. (2005). UML Distilled Edisi 3. Yogyakarta: Andi.

[4] Hendrayudi. (2009). VB 2008 untuk Berbagai Keperluan Programming. Jakarta: PT Elek Media Komputindo.

[5] Hutahaean, J. (2014). Konsep Sistem Informasi . Yogyakarta: Deepublish.

[6] Ibnu Syuhada, M. S. (2015). Inspirasi Codeigniter. Jakarta: Elex Media Komputindo.

[7] Indonesia, K. K. (2011). Buku Panduan Kader Posyandu.

[8] Kusrino. (2007). Srategi Perancangan Dan Pengelolaan Basis Data. Yogyakarta: Andi.

[9] M.Shalhuddin, R. A. (2014). Rekayasa Perangkat Lunak Terstruktur dan Berorientasi Objek. Bandung: Informatika.

[10] Mujiono. (2015). Tutorial Komputer. Diambil kembali dari http://www.teorikomputer.com/2015/10/pengertian -mysql-beserta-kelebihan-dan.html

[11] Pressman. (2010). Rekayasa Perangkat Lunak . Yogyakarta: Andi.

[12] Pressman, R. S. (2012). REKAYASA PERANGKAT LUNAK. Yogyakarta: Andi Publisher.

[13] Pressman.J. (2010). Rekayasa Perangkat Lunak. Yogyakarta: Andi.

[14] Raharjo, B. (2011). Belajar Otodidak Membuat Database menggunakan MySQL. Bandung: Informatika.

[15] Rosa A.S, M. (2014). Rekayasa Perangkat Lunak Terstuktur Dan Berorientasi Objek. Bandung: Informatika.

[16] Rouf, A. (2015). Pengujian Perangkat Lunak Menggunakan Metode Black box dan White Box.

[17] Ryonaldi Yudha Perwira, d. (2014). Sistem Informasi Penjualan Boneka Berbasis Web.

[18] Sawyer, W. (2007). Using Information Technology terjemahan Indonesia. Andi.

[19] Sidik, B. (2012). Pemrograman WEB dengan PHP. Bandung: Informatika Bandung.

[20] Simarmata, J. (2010). Rekayasa Perangkat Lunak. Yogyakarta: ANDI. 
Sri Widaningsih ${ }^{1}$,Fitri Kurnia Efendi ${ }^{2}$, Sistem Pelayanan Posyandu Berbasis Web Sebagai Sarana dalam Meningkatkan Kesehatan Ibu dan Anak Di Posyandu Sartika Cikondang

[21] Subagja, A. (2017). Membagun Aplikasi PHP dengan Codeigneter dan Database SQL Server. Jakarta: Elek Media Kompotindo .

[22] Supono, V. P. (2016). Pemrograman Web dengan Menggunakan PHP dan Framework Codeigniter. Yogyakarta : Deepublish .

[23] Suyanto, A. H. (2007). Step by Step: Web Design Theory and Practices. Yogyakarta: Andi Offset.

[24] Yanto, R. (2016). Manajemen Basis Data Menggunakan MySQL. Yogyakarta: Deepublish. 